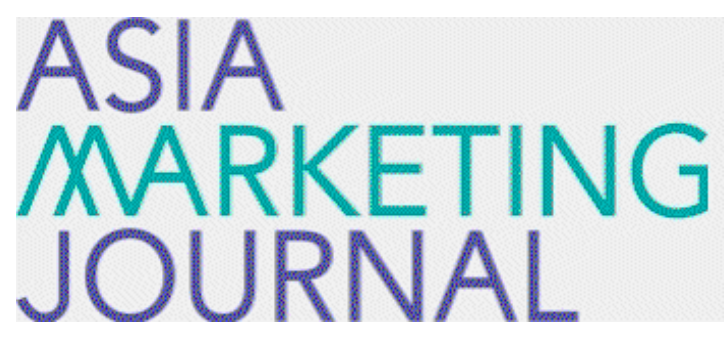

ASIA MARKETING JOURNAL

Volume 16 | Issue 3

Article 7

$10-31-2014$

\title{
Successful Brand Revitalization of Parkland through Brand Repositioning Strategy
}

Jung Ok Jeon

Hyung-Shik Jung

Sukekyu Lee

Lee

Follow this and additional works at: https://amj.kma.re.kr/journal

Part of the Marketing Commons

\section{Recommended Citation}

Jeon, Jung Ok; Jung, Hyung-Shik; Lee, Sukekyu; and Lee (2014) "Successful Brand Revitalization of Parkland through Brand Repositioning Strategy," Asia Marketing Journal: Vol. 16 : Iss. 3 , Article 7. Available at: https://doi.org/10.15830/amj.2014.16.3.101

This Article is brought to you for free and open access by Asia Marketing Journal. It has been accepted for inclusion in Asia Marketing Journal by an authorized editor of Asia Marketing Journal. 


\title{
Successful Brand Revitalization of Parkland through Brand Repositioning Strategy
}

\author{
Jung Ok Jeon* \\ Hyung-Shik Jung** \\ Sukekyu Lee*** \\ Eun Mi Lee Le*** $^{* * *}$
}

\begin{abstract}
Parkland, which is one of the pioneer brands in men's fashion in Korea, specifically suits, has recently undertaken bold brand repositioning activities to respond to the fast-changing environment and to overcome limitations in its current image positioning. As a result, in a short time period, Parkland achieved remarkable marketing and communication success. This case study explains how Parkland drew successful brand repositioning from the fierce fashion market.

This study systematically analyzes the brand repositioning strategy process and implementation strategy used to resolve the conceptual and structural issues of Parkland as a mature brand. To this end, this study assesses Parkland's brand strategy focusing on brand environment and positioning. Accordingly, the study analyzes the target concept and basic direction of the brand repositioning in terms of the repositioning strategy process, and from an integrated marketing perspective, examines the specific implementation program for repositioning. Finally, the study addresses the outcomes of brand repositioning efforts as well as steps to be taken in the future.
\end{abstract}

Key words: Parkland, Brand Repositioning, Revitalization, Positioning, Brand Portfolio

\section{Introduction}

Corporations try to position their new brands when they launch them. The duty of brand managers and marketers is to convey something new about the brand, something that sets it apart from the competition in the minds of customers,

\footnotetext{
* Professor, College of Business Administration, Pukyong National University(jojeon@pknu.ac.kr), First Author

** Professor, College of Business, Chosun University(hsjung@chosun.ac.kr)

*** Professor, School of Business, Sungkyunkwan University(sukekyu@skku.edu)

**** Lecturer, College of Business Administration, Pukyong National University(eilly0328@naver.com), Corresponding Author
} 
clearly establishing its position in the marketplace. As the heart of marketing strategy, brand positioning is defined as "the act of the company's offer and image so that it occupies a distinct and valued place in the target customer's minds" (Kotler and Keller 2012). However, after the initial brand positioning, there comes a time when most brands experience the need for repositioning. A common problem for marketers of established brands is to make them more contemporary by creating relevant usage situations, a more updated user profile, or a renewed brand personality. Mature brands that have been around for years can be seen as trustworthy but also boring, uninteresting, and unfavorable (Keller 2013).

Repositioning should be undertaken when customers' product attitudes have changed, technology development has out-paced the current product, and customers are not accepting the product in the way intended (Shin and Cho 2009). A repositioning strategy is frequently used for fashion brands. The strategy is necessary for the fashion brand to adapt, survive, and beat its competition. Corporations must always be willing to adapt and respond to new market changes. However, since customers' brand attitudes may have become so imbedded that it is not amenable to change, repositioning an existing product may be more challenging than the positioning of a new product. On the other side, in the current market saturation situation, the repositioning strategy, which utilizes existing brand recognition, may achieve its objective more readily because the brand can take hold more quickly in customers' minds. The success of a repositioning campaign depends on whether the intended brand positioning can be flawlessly executed. Thus, brand repositioning is one of the major means of brand revitalization since it provides a new reference point which is suitable for changing target mind caused by the variance and discordance in customer needs and the competitiveness (Min 2005).

Parkland, which is one of the pioneer brands in men's fashion in Korea, specifically suits, has recently undertaken bold brand repositioning activities to respond to the fast-changing environment and to overcome limitations in its current image positioning. As a result, in two short years, it achieved remarkable marketing and communication success. This study seeks to closely analyze Parkland's case of successful brand repositioning in the fierce fashion market. The study thereby draws some theoretical as well as practical implications for brand repositioning, which has not received the level of attention it merits based on its importance.

This case study systematically analyzed the brand repositioning strategy process and implementation strategy used to resolve the conceptual and structural problems of Parkland as a mature brand. To this end, this study assessed Parkland's brand strategy focusing on brand environment and positioning. Accordingly, the study analyzed the target concept and basic direction of the brand repositioning in terms of 
the repositioning strategy process, and from an integrated marketing perspective, examined the specific implementation program for repositioning. Lastly, the study addressed the outcomes of brand repositioning efforts as well as steps to be taken in the future. The study provides practical implications for brand repositioning strategy.

\section{Parkland's Brand Positioning and Repositioning}

\subsection{Parkland's Brand Strategy: Problem and Opportunity}

\subsubsection{Business History}

Parkland, founded in 1973 as a small, bonded garment manufacturing business, has become a fashion business with top, single-brand sales through continued investment and effort. Parkland is a representative company that has successfully converted from a 1980's labor-intensive garment manufacturing business into a high, value-added fashion and distribution business. Currently, it directly manufactures in its hightech factories and markets to customers through nationwide distribution channels.

Parkland was established originally as the Taehwa Textile Company, its previously known name, which manufactured dress shirts including Givenchy and Christian Dior on an OEM basis. There were more than 4,000 garment factories in Korea at the time, with profitability deteriorating following a drastic rise in wages after the 1980's. Therefore, Taehwa moved away from a business model based on bonded-processed exports and, in 1988, launched its own domestic business under the name of Parkland. As Parkland, it succeeded in positioning itself as the representative men's suit brand in Korea. It can be said that the success of Parkland has provided a new business model for converting a labor-intensive garment manufacturing business into a technology-intensive fashion business. Currently, Parkland has five high-tech, directly managed factories and three large logistics centers, and markets multi-brands through diverse distribution channels.

Parkland has now grown into a fashion group with annual sales of more than 600 billion won. It is the only company in Korea that independently manufactures from its own high-tech factories to directly sell to consumers. It has 13 brands including men's wear, women's wear, casual wear, sportswear, and shoes. To proactively meet customers' diverse needs and the distribution environment, it has expanded distribution to home shopping and internet sales, in addition to 560 road shops, fashion malls and marts nationwide. In step with globalization, it has set up a factory in Dalian, China, for more competitive product manufacturing and supply as well as entry into the Chinese market. For business diversification, it also operates an OEM sports shoe factory 
which produces world-famous brands such as New Balance and Adidas in Indonesia.

Parkland's vision is to become a "company leading everyone's happiness and winning everyone's endearment," and its mission is "the creation of new values in life and living culture for a better tomorrow." The company has a sales target of 1.5 trillion won for 2020, and it is implementing diverse efforts to strengthen its product competitiveness, marketing competitiveness, enhancement of human resources management, and global competitiveness.

\subsubsection{Brand Portfolio}

Currently, as shown in Figure 1, Parkland is pursuing market positioning as a corporate brand and a family brand as well as an individual brand. Parkland's target customers are those in middle to late-middle age who prefer comfort- able and practical brands. Therefore, by focusing its marketing efforts on its core brand, Parkland, it seeks to maximize customer satisfaction while at the same time adopting a total brand strategy and launching sub-brands, seeking to adjust to changing customer needs and market environment. Parkland's men's wear was marketed via stores under the family brand Parkland, J. Hass targeted at younger customers, and Cabrini at highend customers. However, these latter two brands were intended more as expansions of the product line rather than independent brands.

In the beginning, Parkland followed a strategy of building new markets by focusing on customer's purchasing behavior. For example, it focused on the facts that men's suits are highly purpose-driven purchases and that customers are gradually becoming more restrained in their spending. Therefore, it established a strategy for building a mid-to-low priced market, which

〈Figure 1〉 Parkland's Brand Portfolio

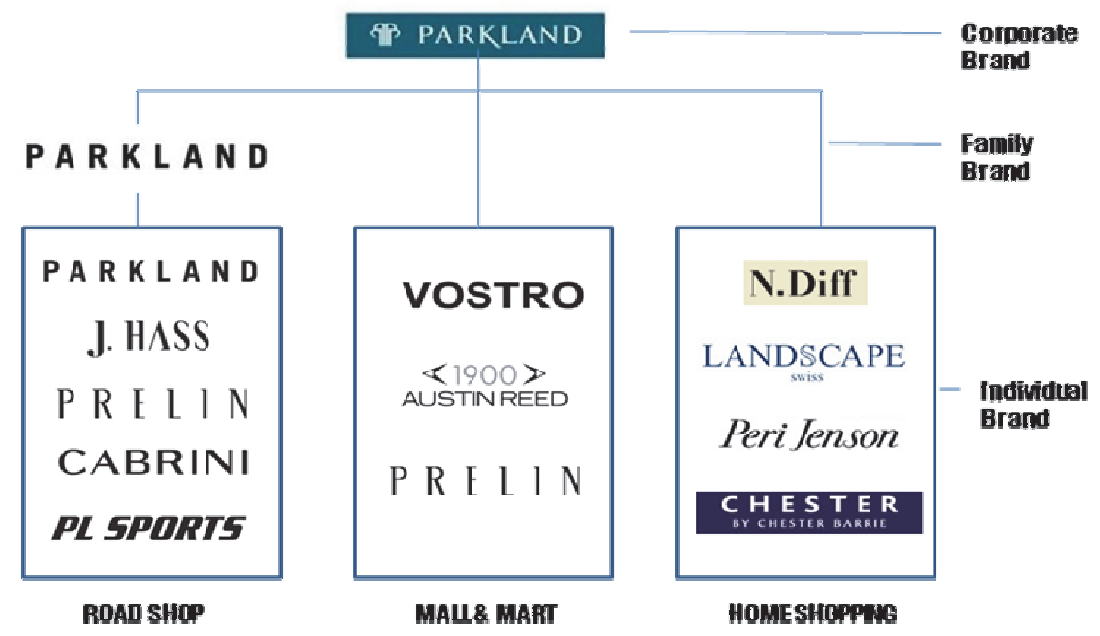

104 ASIA MARKETING JOURNAL Vol. 16 No. 03 October 2014 
was a new segment, created through the customer's changing needs. As a result, it created the one unified brand of "Parkland." Following that, in the early 2000s, with the sudden rise of character casual wear and its expanding market share, the company responded by launching "J. Hass." In 2010 as a turning point, male customers, centering around the young male shoppers leading the change, started adopting new fashion at an increased speed to accentuate their own personality. The men's wear industry, which at the time did not have a clearly defined store concept, came out with interior designs appropriate to each of brand concept, as well as theme shops. Also, the character casual brands and contemporary brands showed strong sales.

At a time when men's wear brands were pushing forward with brand extensions, in line with spending patterns and changes in marketing, Parkland, realizing its need to convert to a total fashion brand from just a men's suit brand, launched the high-end brand "Cabrini" and active sportswear "PL Sports", as well as
"Prelin" for female customers shopping with male customers, to enable one-stop shopping within the Parkland stores (see Figure 2).

Parkland's approach has been to adopt a strategy establishing its identity as a store brand first and then take steps to strengthen its brand. In order to move away from its old image and expand its customer base, it strengthened the sub-brand concept and the roles of these brands within the stores.

Prior to the repositioning, sub-brands like J. Hass served the role of merely supporting various age group and purchase needs within the Parkland stores. However, following the repositioning, sub-brand zoning within the stores was reinforced, and by supplementing marketing and facilities, including signage, it strengthened its own brand traits. In addition, through sales training, it focused on raising customer awareness of its sub-brands. As a result, the ratio of customers who recognize the sub-brands such as Prelin, J. Hass, and Cabrini increased as well as the customers visiting the stores with

〈Figure 2〉 Parkland's In-house Brands

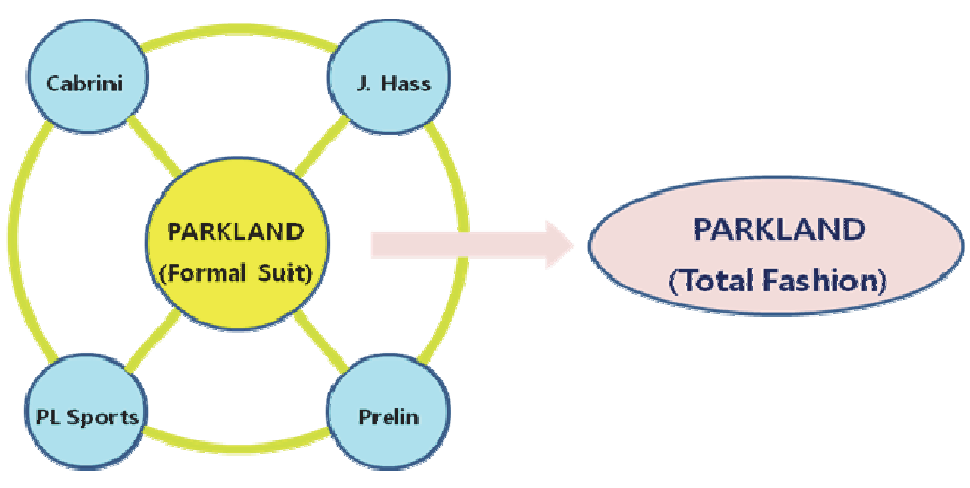

Successful Brand Revitalization of Parkland through Brand Repositioning Strategy 105 
the intent to purchase these brands. Moreover, through the sub-brands, Parkland succeeded in solidifying the awareness that Parkland stores are where shopping for formal wear, as well as casual wear and sportswear, is possible, irrespective of age or gender. The roles of Parkland's in-store brands are summarized in Table 1.

\subsubsection{Business Positioning Analysis}

However, despite the Parkland's continued positioning efforts, it found, through a number of consumer surveys, that the image of "good clothing, good price," which was Parkland's strong point, did not adequately reflect customer needs in accordance with current consumer trends (see Figure 3). In particular, it learned in the FGI and consumer survey, conducted in 2011 among store operators, general customers and regular customers indicated that Parkland failed to shed its "old, cheap, and conservative image."

In addition, because Parkland filled three roles as corporate brand, family brand, and individual brand, there were issues with having to act as supporter for the various sub-brands within the same store. Therefore, since customers did not recognize the sub-brands as individual brands, but more frequently as Parkland's product lines, the conveyance of the individual brand concept was rather weak.

\subsection{Brand Repositioning Strategy}

Ryan et al. (2007) asserted that the repositioning process should be evolutionary, pragmatic, and built on existing capabilities. Likewise, Parkland's commitment to the repositioning strategy was steadfast and was designed in due order based on analysis of market research and customer feedback.

In 2012, Parkland undertook repositioning to revitalize its brand by improving its limited images and reinterpreting the brand's core values. The core value of "good clothing, good price" was reinterpreted as for the times and values. That is to say, the repositioning of each brand in the minds of the customers as

〈Table 1〉 Roles of Parkland's In-house Brands

\begin{tabular}{|c|c|c|c|c|c|}
\hline & PARKLAND & J. HASS & CABRINI & PRELIN & PL SPORTS \\
\hline $\begin{array}{l}\text { Brand } \\
\text { Role }\end{array}$ & family brand & $\begin{array}{l}\text { silver bullet } \\
\text { brand }\end{array}$ & niche market & strategic brand & $\begin{array}{l}\text { supplementation } \\
\text { brand }\end{array}$ \\
\hline TPO & everyday suit & first trial & $\begin{array}{l}\text { important day } \\
\text { /meeting }\end{array}$ & $\begin{array}{c}\text { on duty, } \\
\text { important meeting }\end{array}$ & active sportswear \\
\hline Target & $\begin{array}{c}3049 \\
\text { office worker }\end{array}$ & $\begin{array}{c}2534 \\
\text { society beginner }\end{array}$ & $\begin{array}{c}\text { professional } \\
\text { /senior manager }\end{array}$ & $\begin{array}{l}\text { career woman, } \\
\text { housewife }\end{array}$ & outdoor activist \\
\hline $\mathrm{KBF}$ & $\begin{array}{l}\text { practical \& } \\
\text { reasonable }\end{array}$ & $\begin{array}{l}\text { character \& } \\
\text { stylish }\end{array}$ & social \& prestige & $\begin{array}{c}\text { basic \& } \\
\text { career-oriented }\end{array}$ & practical \& active \\
\hline
\end{tabular}


〈Figure 3〉 Parkland's Brand Associations

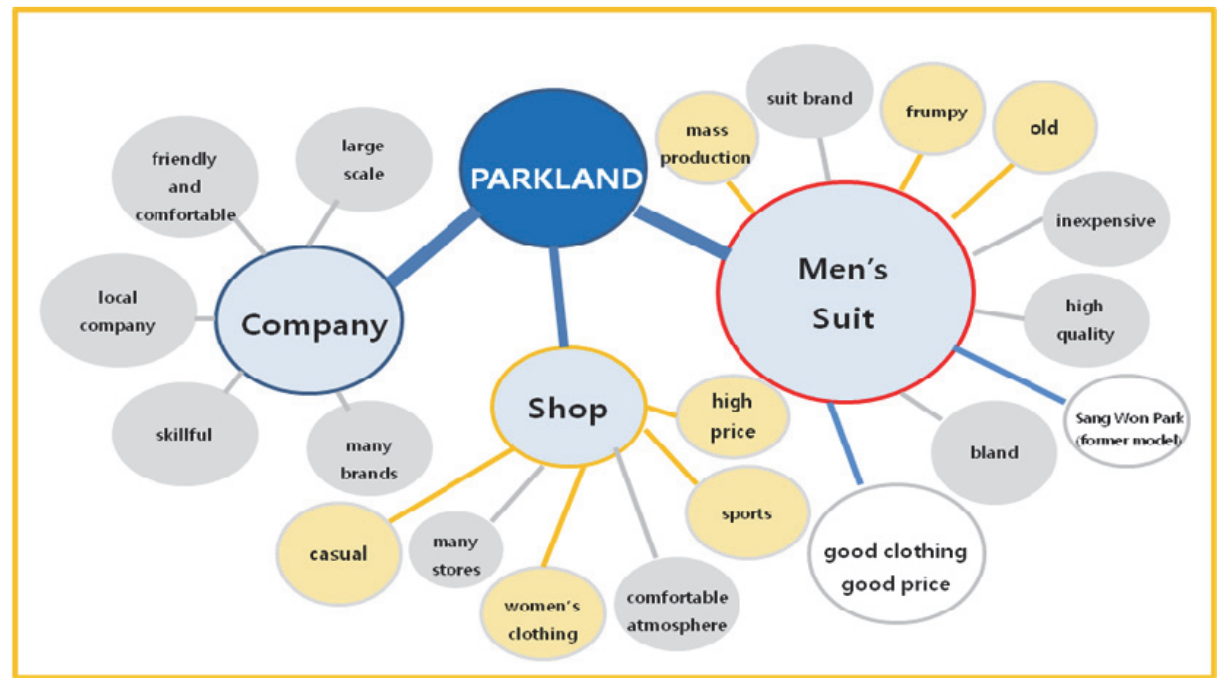

Source: Daehong Communications, Qualitative Research (respondents: 30s), 2010. 9

"younger and sophisticated clothing with design sense" rather than "good clothing = good quality, good price $=$ cheap price."

In its consumer survey conducted in 2011, as illustrated in Figure 4, Parkland analyzed the areas which needed to be continuously maintained, not only maintained but also reinforced, gradually improved, and be improved with ut-

〈Figure 4〉 Brand Repositioning Concept

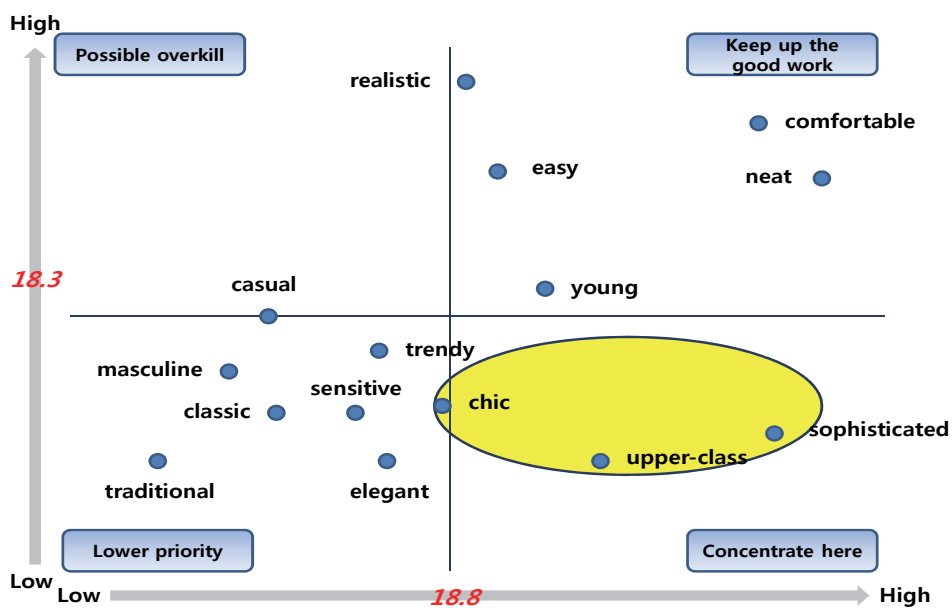

Source: Parkland, Consumer Survey, 2011 
most priority. As a result, it pursued repositioning through a sub-brand concept adjustment and role re-authorization.

Parkland re-adjusted the positioning of J. Hass to maintain its "neat, comfortable, and reasonable" image, while targeting younger customers pursuing trendiness by adding a "chic, young, modern, and fashionable" element. In addition, the positioning of Cabrini was re-adjusted to reinforce a "luxurious and classy" image (see Figure 5). As a result, in-house brands of Parkland were re-adjusted on the basis of two standpoints, generation value and sensitivity value, for the welldefined repositioning as illustrated in Figure 6.

〈Figure 5〉 Brand Repositioning Map

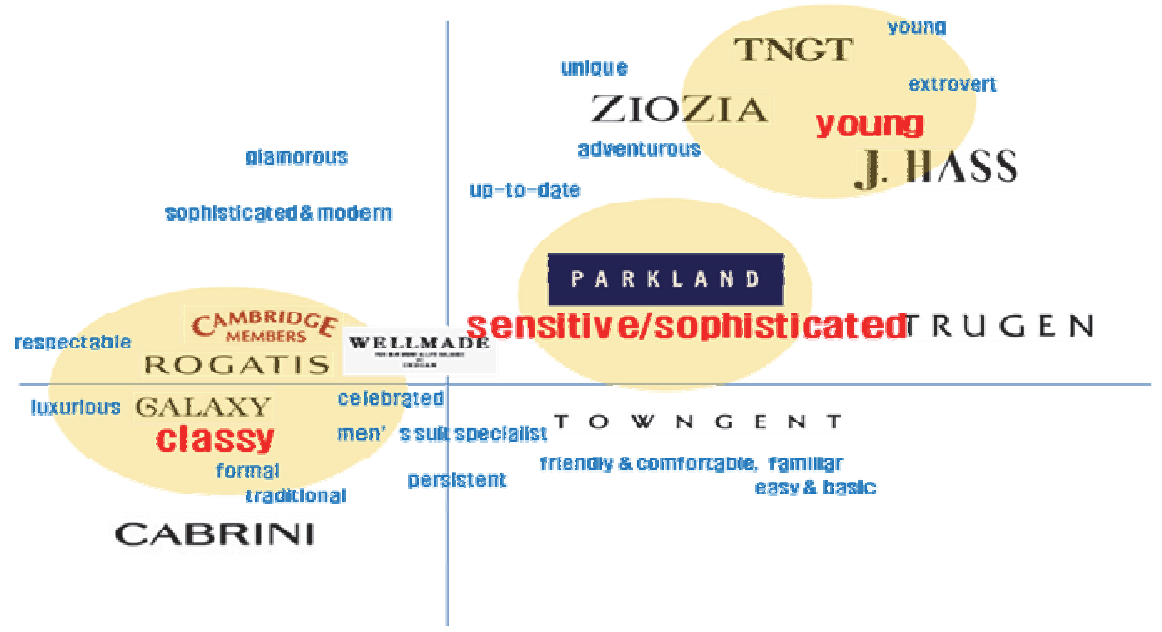

〈Figure 6〉In-house Brands Repositioning

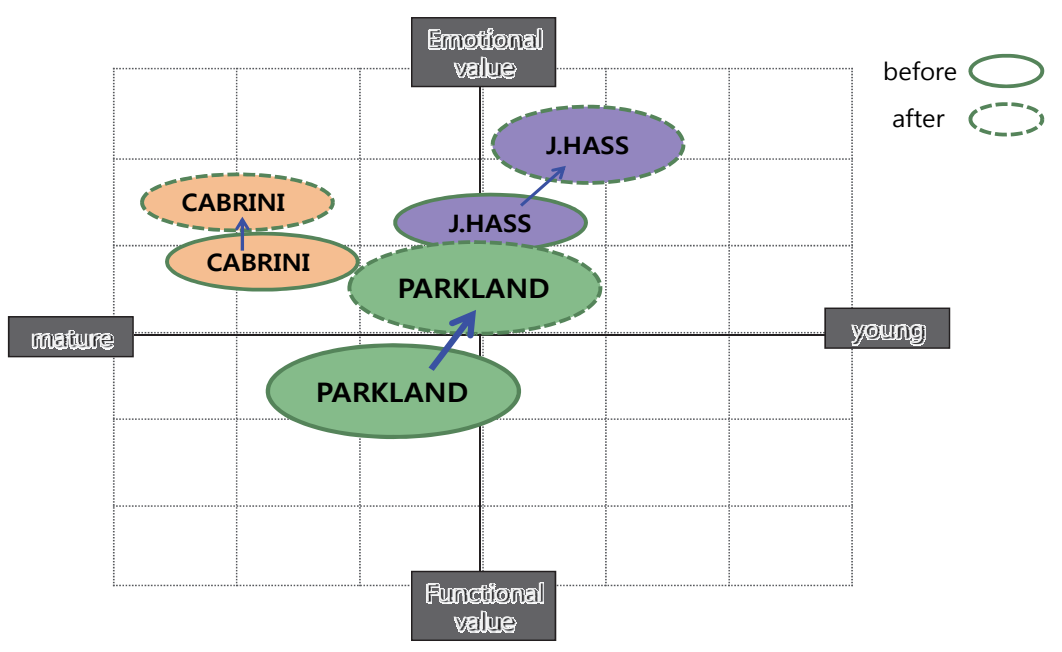

108 ASIA MARKETING JOURNAL Vol. 16 No. 03 October 2014 


\section{Brand Repositioning Strategy of Parkland}

\subsection{Brand Identity (BI) Strategy}

Parkland, which is considered as the representative brand in men's suits based on its practicality and dignity of suits, established a new brand identity to increase brand value by moving away from its former image as a "suit for those of middle to late-middle aged," and renewed and reinforced its marketing accordingly.

Parkland had used same BI and Corporate Identity (CI) to reinforce its image as a fashion company, but it decided to adopt a strategy of separating its $\mathrm{BI}$ and $\mathrm{CI}$ to strengthen its trendiness and the concept of Parkland as a family brand and an individual brand.

Whereas the sense of size, dignity, and reli- ability of a total fashion company had been emphasized in the previous $\mathrm{BI}$, the renewed BI underscored youth and fashion. The new BI is based on the concept of "Forever Heritage," popularizing the unwavering value of classic and comfortable dignity. To reinforce its youthful image, Parkland changed to a simpler logotype, and its color system changed to a more luxurious and basic color.

Parkland implemented Shop Identity (SI) renewal along with $\mathrm{BI}$ change. Its previously cold and dignified SI was changed to a contemporary styled men's wear store, where sense of style and comfort coexist, using modern and minimalistic natural wood point (see Figure 7).

\subsection{Retailing Strategy}

Parkland undertook an all-out SI launch and store renewal, along with BI change and store

〈Figure 7〉 Bl and SI Renewal

Before

\section{$\S \mathbb{P}$ PARKLAND}

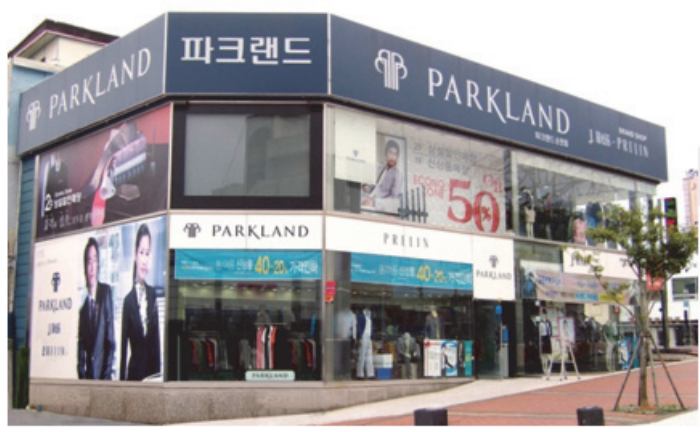

After
P A R K L A N D

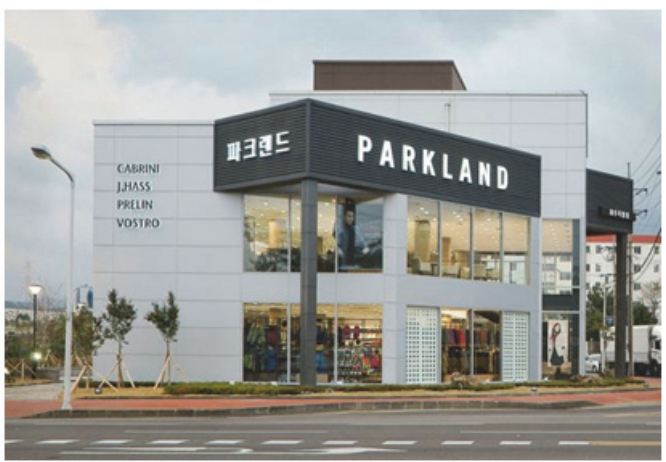


atmosphere improvement. The work on outdated interiors, facilities, and signage, pointed to as major causes of damage to Parkland's brand image, was conducted simultaneously. This resulted in a bold change in store atmosphere that went beyond a simple BI change and signage replacement. In addition, the visuals such as POP and objet seen at the customer contact points were refurbished simply and luxuriously through consultation with experts. Those stores that have undergone renewal work had significant impact on the change in the Parkland image among existing and new customers, confirmed in consumer surveys.

In addition to the improvement in the store environments, Parkland also strengthened local marketing on a store-by-store basis. Focusing on the fact that sales patterns and customer tastes differ, depending on the areas where the stores were located, the company moved away from simply applying the same sales management, marketing, and product strategy to all stores and established a system where the storeowners and managers were seen as control towers in the given communities, and marketing and promotion strategies were customized for the needs of each store.

On the other hand, the company realized that to change the image of being mid-to-low priced and old, there was a need for large-sized stores and directly-operated stores to have service and store atmospheres that befit their products and marketing. Therefore, starting in the mid-2000s, the company increased the ratio of large-sized and directly-operated stores, previously less than $10 \%$, to $20 \%$ in 2013. Although the large-sized stores and directly-operated stores carried the burden of high rents and interior costs, they succeeded in obtaining the approval of consumers, playing the role of flagship stores in their areas. Through this, they improved Parkland's brand image and provided services and an environment that are distinguishable from small and medium-sized stores.

The training of the manager and sales representatives who are at the center of customer communication was also a core element in the strategic change in the store environment. Parkland holds briefing sessions for new products twice a year for SS (spring/summer) and FW (fall/ winter) seasons. The managers and sales representatives who visit the sessions have the opportunity to evaluate the first- and secondhalf year's new products, along with the designers and MDs (merchandising directors), and conduct training for sales and marketing strategies. In addition, beside the autonomous training for the directly-run stores throughout the year, the managers and sales staffs receive training on products and service marketing through collective training provided by the headquarters. Moreover, there is a system where the sales managers continuously collect data on various store aspects, such as service and interiors, and by evaluating these, reflect these into the incentives of managers and sales staffs. Additionally, the 
company regularly invites many sales and promotion experts in the industry to operate the Sales Academy to train on outstanding service skills and customer management know-how. In particular, in order to raise the level of service quality in directly-operated stores, the sales staffs in these stores are referred to as "stylists" and training is offered accordingly every quarter. This led to high customer satisfaction ratings. In addition, the Corporate MBA program is provided to back-office employees at the headquarters in three different work areas. This program allows employees the opportunity to acquire practical knowledge from reputable college professors and experts.

\subsection{Product Strategy}

Following its repositioning, Parkland experienced a substantial turnabout in terms of product planning to attract new young customers. Based on sales data analysis of existing customers, while the basic product line, which was similar from one year to the next, was reduced, the young, trendy-styled product line was expanded.

Parkland and Cabrini reduced their production volume while J. Hass increased it from 16\% in 2011 to 20\% in 2012 and to 25\% in 2013 (see Figure 8). The products introduced by J. Hass are targeted at young fashionable customers. At the same time, the level of quality was raised through internal specification details of such as boutonnieres, handkerchiefs, and interior linings. J. Hass took the strategy of maximizing its attraction by reinforcing a trendy sense of color and details for potential young customers who will be wearing their first suit and through promotions aimed at graduations and hiring seasons.

At the same time, Parkland also focused on

〈Figure 8〉 Production Share Change by Brand

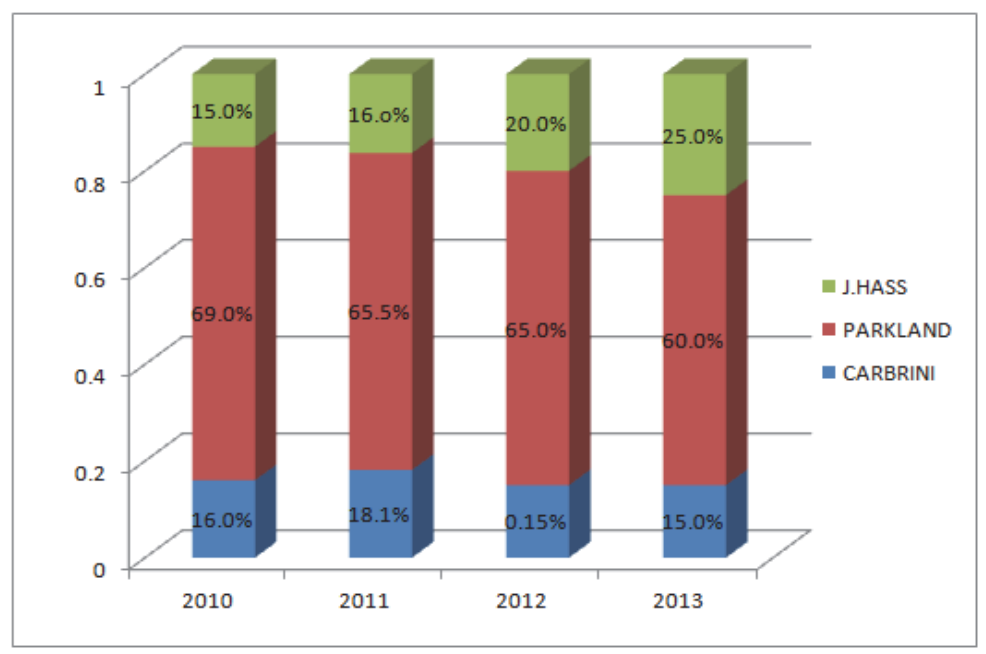


reinforcing its image as a basic, yet practical suit for those businessmen who wear suits to work. By using the best quality materials and specifications for those special customers who prefer an Italian styled distinguished look, Cabrini actively sought to differentiate itself from the competition as a prestige brand within the store. By concentrating on clarifying the roles and concepts among brands, Cabrini was able to stand at the desired status.

\subsection{Integrated Marketing Communications (IMC) Strategy}

Even though Parkland still had the best brand power among men's suits, it believed it was at a stage where it needed brand revitalization because when it looked closely at two aspects that constitute brand power, freshness and loyalty, it found it was stuck in an area where loyalty was high but freshness was low. In this context, Parkland sought to efficiently convey brand repositioning to customers by successfully conducting IMC, with the goal of enhancing the value of its brand equity through increased brand freshness.

Based on an understanding that consumers were no longer drawn to Parkland's catch phrase "good clothing, good price," the company excluded keywords such as factory, price, and quality from advertisements and changed direction, moving instead to trendy and young styled advertisements. To this end, the com- pany replaced its existing model, going to Jo In Sung, an icon representing a trendy and sophisticated style. At the same time, to change their perception among young customers, the company introduced creativity that was differentiated from previous advertisements.

Prior to the advertising change, the main copy was "good clothing made with design engineering, good price, Parkland." Since then, with the concept change, the new copy became "Do you think you know Parkland?" as the core of the advertising creative. In this way, the company paradoxically implied that although customers think they know Parkland, when they actually see the current products, they will see diverse styles and styles far surpassing their expectations. This approach magnified the new expectations around Parkland with "Beyond expectation= Parkland." In particular, Jo In Sung's playful line, "You'd be surprised," countered Parkland's previously heavy and old image and repositioned it in a stylish, young image (see Figure 9).

In addition to the creative strategy, the media strategy was also carried out in a differentiated manner. Whereas, previously, the ratio of ATL (above-the-line) advertisements centered on four major media outlets was high, BTL (below-the-line) advertisements, targeting customers in their 20s and 30s, was reinforced to expand the customer base. Table 2 summarized how Parkland changed IMC strategy in detail to suit the IMC objectives for the successful repositioning. In accordance with IMC strategy, 
〈Figure 9〉 Creative Concept Change for TV Advertising

Design Engineering(2009)

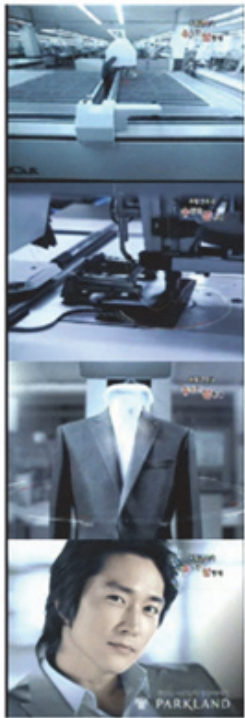

Beyond Expectation(2012)

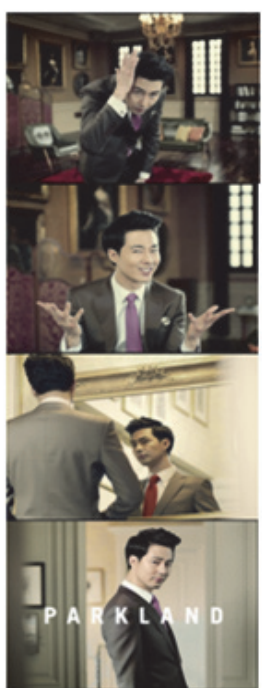

〈Table 2〉 IMC Strategy Change

\begin{tabular}{|c|c|c|}
\hline & $\begin{array}{l}\text { before Repositioning } \\
\text { (rational appeal) }\end{array}$ & $\begin{array}{l}\text { after Repositioning } \\
\text { (emotional appeal) }\end{array}$ \\
\hline Creative strategy & $\begin{array}{l}\text { - communication strategy focused on } \\
\text { rational value } \\
\text { - reasonable, credible, imposing }\end{array}$ & $\begin{array}{l}\text { - IMC strategy focused on emotional value } \\
\text { - fresh, young, sophisticated }\end{array}$ \\
\hline Celebrity strategy & $\begin{array}{l}\text { Song Seung-heon : rational and } \\
\text { credible model }\end{array}$ & $\begin{array}{l}\text { Jo In sung : young, modern and sophisticated } \\
\text { model }\end{array}$ \\
\hline Media strategy & $\begin{array}{l}\text { real target (40s) oriented ATL media } \\
\text { especially TV }\end{array}$ & $\begin{array}{l}\text { Young target (late 20s - 30s) oriented ATL } \\
\text { \& BTL media }\end{array}$ \\
\hline Promotion strategy & sales promotion oriented execution & $\begin{array}{l}\text { reinforcing customer participatory event promotions } \\
\text { and brand image renewal activities }\end{array}$ \\
\hline
\end{tabular}

as shown in Figure 10, the share of BTL was increased up to $36 \%$.

In terms of communication with young customers, the company reinforced two-way communication through SNS channels (e.g., selfoperated Blog, Facebook, and Twitter, viral ac- tivities thru café and community). In addition, for the brand to be naturally exposed at the contact point with a customer, TV PPL, Golf Zone, vehicle wrapping advertising, subway screen doors, and various other BTL media were used to convey a younger and stylish Parkland brand 
〈Figure 10〉 Share of Voice (ATL/BTL) by Year

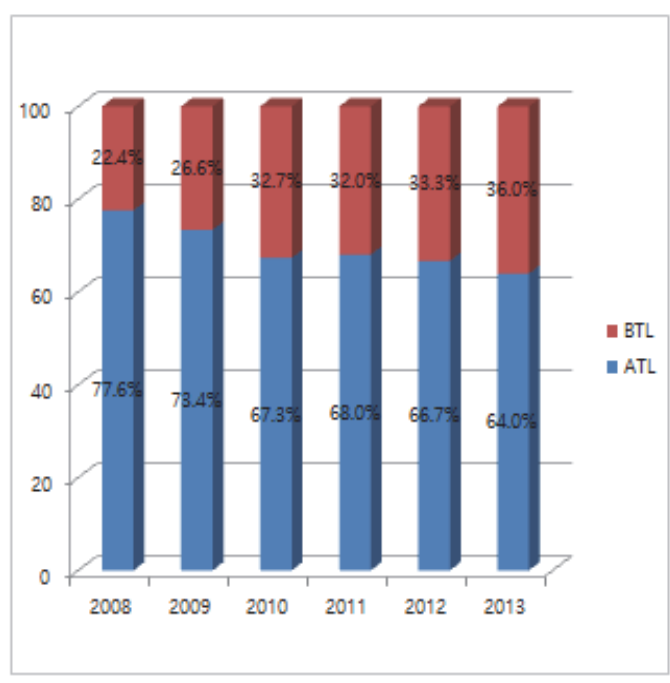

\begin{tabular}{|c|c|c|c|c|c|c|c|}
\hline & & 2008 & 2009 & 2010 & 2011 & 2012 & 2013 \\
\hline \multirow{8}{*}{ ATL } & TV & 56.0 & 45.1 & 26.0 & 27.7 & 43.9 & 33.3 \\
\hline & CATV & 9.6 & 15.6 & 16.2 & 9.1 & 8.5 & 10.0 \\
\hline & RADIO & 0.3 & 0.0 & 5.4 & 5.5 & 2.1 & 7.7 \\
\hline & newspaper & 6.2 & 6.9 & 10.8 & 14.2 & 4.1 & 7.7 \\
\hline & magazine & 1.4 & 2.8 & 5.5 & 8.2 & 4.2 & 2.2 \\
\hline & internet & 2.0 & 2.9 & 3.4 & 1.5 & 2.3 & 1.2 \\
\hline & theater & 2.1 & 0.0 & 0.0 & 2.0 & 1.6 & 1.9 \\
\hline & total & 77.6 & 73.4 & 67.3 & 68.0 & 66.7 & 64.0 \\
\hline \multirow{6}{*}{ BTL } & bus ad & 0.0 & 0.0 & 0.2 & 0.6 & 1.1 & 0.3 \\
\hline & outdoor ad & 20.0 & 23.2 & 27.0 & 22.9 & 18.3 & 31.4 \\
\hline & SNS & & & & & 1.0 & 1.4 \\
\hline & $\mathrm{PPL}$ & 0.0 & 0.0 & 0.0 & 3.8 & 8.9 & 1.0 \\
\hline & etc & 2.4 & 3.4 & 5.4 & 4.6 & 4.0 & 1.9 \\
\hline & total & 22.4 & 26.6 & 32.7 & 32.0 & 33.3 & 36.0 \\
\hline
\end{tabular}

image. Moreover, for two-way communication with customers in their 20s, who are the future growth engine, the company continuously hold various events such as college student rallies, design contests, and customer participatory SNS events.

\section{Conclusion}

\subsection{Business Repositioning Performance}

Although only a short time has elapsed since its major repositioning, Parkland has already accomplished more than expected.

First, as shown in Figure 11, the enrollees in Parkland Membership are recently increasing rapidly, particularly the new young members who are the growth engine of the future. Also, since 2012, following the repositioning, despite the shrinkage of general fashion brands, Parkland's sales growth are noticeably increasing at a rate of 5 to $10 \%$ over two consecutive years (see Figure 12). These can be seen as the results of the repositioning and an improvement in the perception among consumers who experiencing the new Parkland through products, store atmosphere, and IMC.

Second, in the FIBA survey, conducted in the first half of 2014, analyzing the suit brands purchased most frequently by male consumers in the past six months, Parkland was ranked number one in the men's suits category, at an equal level of preference across all age groups. The result can be confirmed in Table 3 below. Due to the enhancement in brand equity, Parkland was able to win the Korea Top Brand Award 
〈Figure 11〉 Enrollees in Parkland Membership by Age

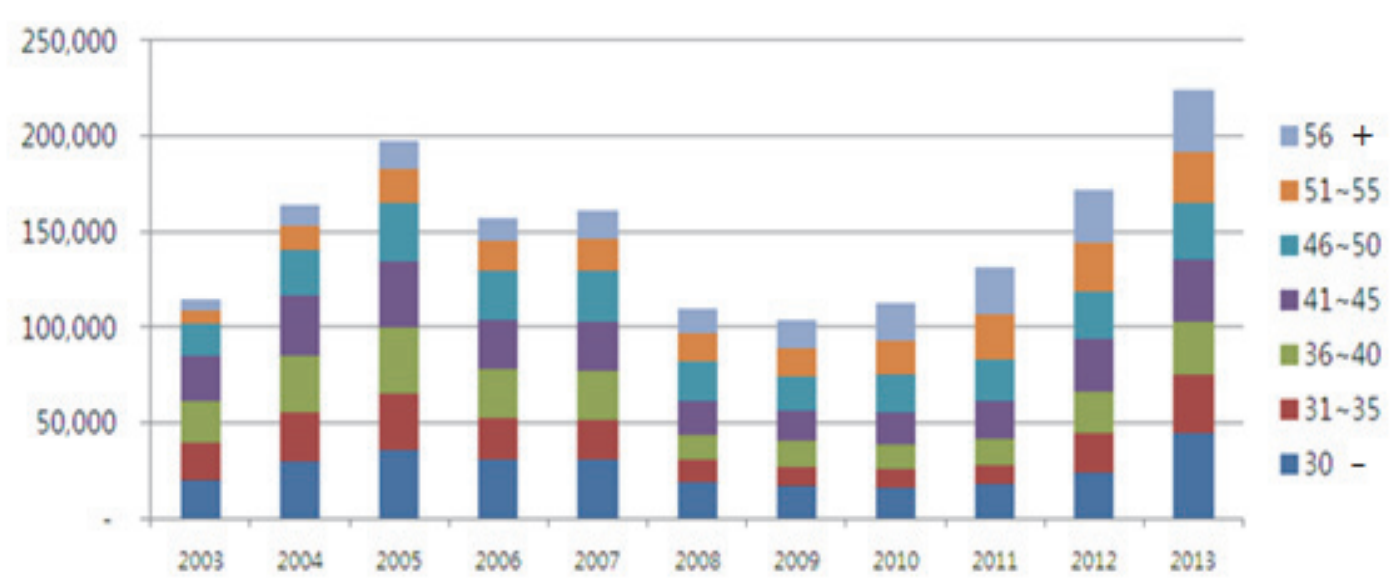

〈Figure 12〉 Yearly Sales Growth of Parkland

(unit: \%)

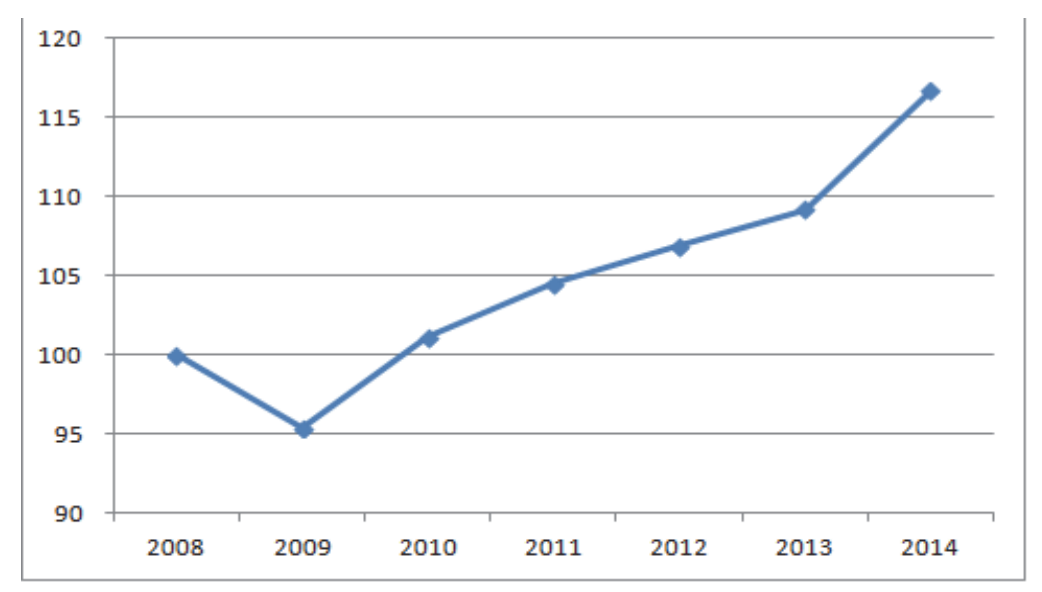

for 10 consecutive years, the National Customercentered Brand Award, and Marketing Frontier Award, acknowledging Parkland's significant brand awareness and image. Through such repositioning, Parkland was able to ultimately make consumers, who have grown tired of their marketing since 1988 based on their reasonable prices and high-tech factories, aware of Parkland as a young and stylish brand. In that sense, it can be said this is a case where the brand revitalization strategy was most appropriately carried out just before a brand decline.

Third, in terms of invoking an image, the old Parkland was positioned as "low price, good quality," "mid to low price - convenience," so the expansion of "young," "stylish," "chic," and 
〈Table 3〉 Men's Suit Brands Purchased Most Frequently

(response rate, unit: \%)

\begin{tabular}{|c|c|c|c|c|c|c|c|c|c|c|c|}
\hline \multicolumn{2}{|l|}{1319} & \multicolumn{2}{|l|}{2024} & \multicolumn{2}{|l|}{2529} & \multicolumn{2}{|l|}{3039} & \multicolumn{2}{|l|}{4049} & \multicolumn{2}{|l|}{5059} \\
\hline none & 52.0 & none & 29.0 & none & 21.0 & none & 14.0 & PARKLAND & 15.0 & none & 16.0 \\
\hline GIORDANO & 4.0 & GIORDANO & 11.0 & ZIOZIA & 12.0 & PARKLAND, ZIOZIA & 10.0 & none & 13.0 & GALAXY & 13.0 \\
\hline $\begin{array}{c}\text { PARKLAND, } \\
\text { NIKE, } \\
\text { JOYHOMME }\end{array}$ & 3.0 & PARKLAND & 8.0 & $\begin{array}{c}\text { PARKLAND, } \\
\text { UNIQLO }\end{array}$ & 6.0 & SIEG & 9.0 & GALAXY & 9.0 & DAKS & 8.0 \\
\hline \multirow{4}{*}{$\begin{array}{l}\text { SPAO, GUCCI, } \\
\text { BEAN POLE, } \\
\text { BILTMORE, } \\
\text { ADIDAS, } \\
\text { UNIQLO, } \\
\text { ZIOZIA }\end{array}$} & \multirow{4}{*}{2.0} & GIORDANO & 6.0 & STCO & 5.0 & STCO & 5.0 & TOWNGENT & 5.0 & ROGATIS & 7.0 \\
\hline & & UNIQLO & 3.0 & TNGT, SIEG & 4.0 & TNGT & 4.0 & BASSO & 4.0 & $\begin{array}{l}\text { CAMBRIDGE } \\
\text { MEMBERS }\end{array}$ & 4.0 \\
\hline & & \multirow{2}{*}{$\begin{array}{l}\text { NORTH FACE, } \\
\text { BASSO, } \\
\text { WELLMADE }\end{array}$} & \multirow[b]{2}{*}{2.0} & $\begin{array}{c}\text { BON, } \\
\text { made-to-order } \\
\text { suit, } \\
\text { BEAN POLE, } \\
\text { GIORDANO }\end{array}$ & 3.0 & $\begin{array}{c}\text { GALAXY, } \\
\text { made-to-order suit }\end{array}$ & 3.0 & $\begin{array}{l}\text { LG FASHION, } \\
\text { ROGATIS, } \\
\text { MAESTRO, } \\
\text { BEAN POLE, } \\
\text { CAMBRIDGE } \\
\text { MEMBERS, } \\
\text { KOLON, HAZZYS }\end{array}$ & 3.0 & $\begin{array}{c}\text { CHEIL } \\
\text { INDUSTRIES, } \\
\text { TOWNGENT }\end{array}$ & 3.0 \\
\hline & & & & $\begin{array}{l}\text { ZARA, } \\
\text { BASSO, } \\
\text { MVIO }\end{array}$ & 2.0 & $\begin{array}{l}\text { RENOMA, MVIO, } \\
\text { BEAN POLE, } \\
\text { WELLMADE, } \\
\text { CAMBRIDGE } \\
\text { MEMBERS, } \\
\text { KINLOCH, TRUGEN, } \\
\text { TOMMY HILFIGER, }\end{array}$ & 2.0 & $\begin{array}{l}\text { DAKS, UNIQLO, } \\
\text { SIEG, POLO, } \\
\text { PIERRE CARDIN }\end{array}$ & 2,0 & $\begin{array}{l}\text { LG FASHION, } \\
\text { MAESTRO, } \\
\text { BEAN POLE, } \\
\text { UNIQLO, } \\
\text { ZIOZIA }\end{array}$ & 2.0 \\
\hline
\end{tabular}

Source: FIBA research (2014)

"trendy" images, to attract the target customer base of consumers in their 30s, was achieved. Also, following the IMC campaign led by new advertisements, those consumers who were exposed to these recognized the new brand image (see Figure 13). Therefore, the communication turned out to be a success.

\subsection{Future Challenges}

This study thus far examined the successful brand repositioning strategies implemented by Parkland for brand revitalization. Parkland's success case put to rest concerns over the limited image associations. Therefore, it is meaningful for companies and brands seeking to revitalize their brand images. Although Parkland had satisfactory success in its repositioning strategy, it needs to make efforts on the following few items in order to firmly position itself in its new direction.

First, mid-to long-term brand portfolio strategy must be established based on fashion distribution and the consumer environment. From a long-term perspective, there needs to be serious consideration of the stereotypical structure of the brand hierarchy inherent in Parkland's unique brand role: "Corporate brand=store brand =family brand=individual brand." Although the mature Parkland brand has accomplished relative image improvement through repositioning, it will be very difficult to completely resolve 
〈Figure 13〉 Brand Image Change of Parkland by Ad Viewing
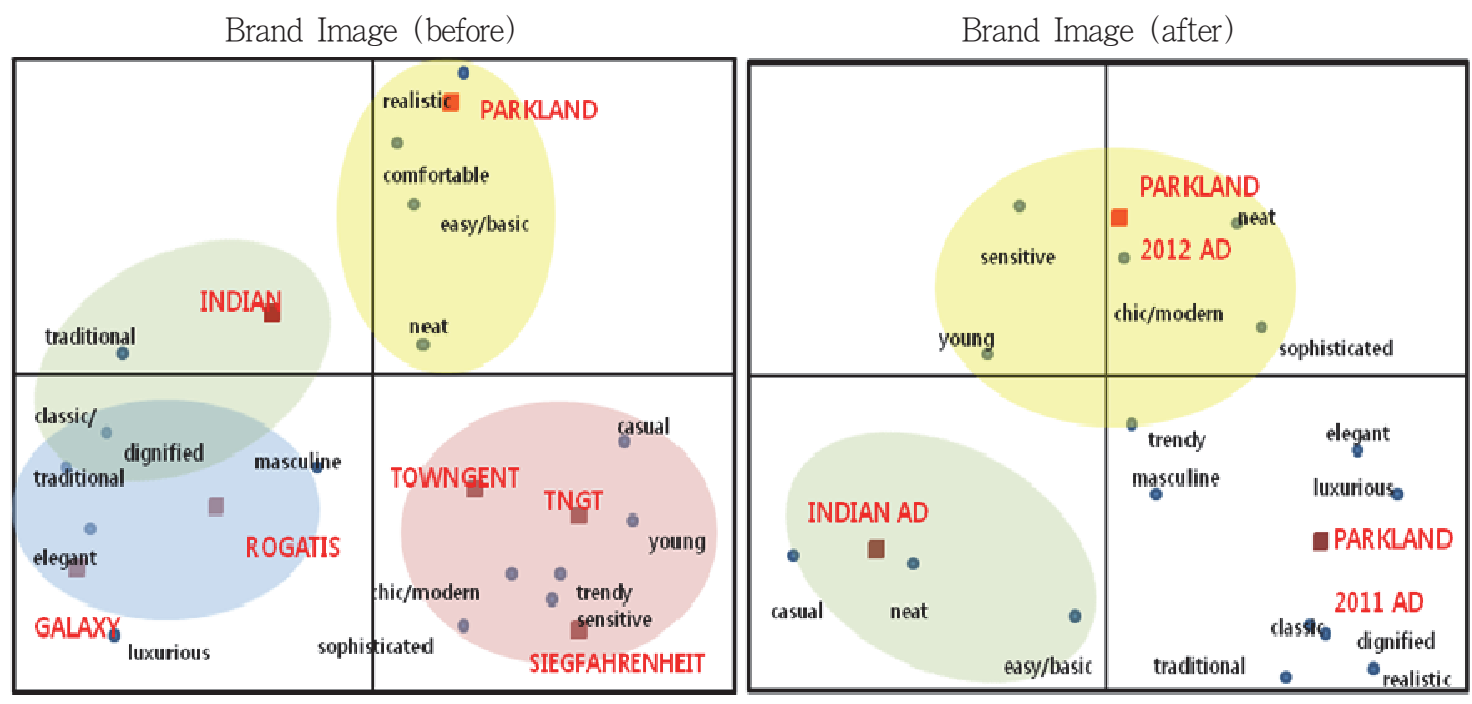

Source: embrain, Parkland Ad Effect Research (2012. 7)

the fundamental and structural image limitations that Parkland has. To proactively access market opportunities in the changing fashion environment, it is necessary to prospectively examine the excessive roles of Parkland. Along with this, there is also a need to recognize the issues relating to realistic restrictions on brand and product categories that suit the hybrid distribution and trend towards increasing store size. In particular, plans should be actively sought for realizing brand diversity, not only through a balance between brands, but through brand strategy for casual wear and the sportswear category.

Second, the role of the Parkland brand, which is the store brand as well as the family brand, is positive in that it creates synergy, but there are concerns over the fact that it could harm the independent images of the separate brands within the stores. In that sense, there is a fundamental question as to whether the Parkland brand should be reinforced as a store brand or the competitiveness of the individual brands should be strengthened. Although there are many elements of consideration in this regard, from a long-term perspective, there is a need for a strategy to first develop the competitiveness of each brand to enhance its influence as independent brands. To this end, it will help rebuild Parkland's store image to more clearly differentiate the role of brands in-store to secure the mutual independence of brand images.

Third, in terms of brand revitalization, there is a need for to build an integrated marketing system for the acceptance of and adaption to constant change attendant in brand repositioning. For example, some issues were partially exposed 
in the re-adjustment of the integrated positioning and communication within the organizational structure made up of existing marketing, products, and sales. To this end, it is suggested that the brand marketing department, considering the uniqueness of a fashion company, must lead the management to integrate, readjust, and implement with the initiatives regarding positioning and communication.

There is also a need to consider the use of big data for sophisticated implementation of repositioning and the enhancement of marketing efficiency. This means strengthening marketing by using big data for brand revitalization and to win in the market. To this end, cool-headed recognition and judgment around the current CRM strategy is required, and this implies that a big data system must be prospectively adopted along with the necessary infrastructure.

〈Received June 16. 2014〉

$\langle$ Revised August 16. 2014〉

〈Accepted October 22. 2014〉

\section{References}

Keller, Kevin Lane (2013), Strategic Brand Management, 4th ed., Pearson Education Limited, Essex, England.

Kotler, Philip and Kevin Lane Keller (2012), Marketing Management, $14^{\text {th }}$ ed., Prentice Hall, Upper Saddle River, NJ.

Min, Min Shik (2005), "Brand Repositioning Strategy," KAA Journal, 7(4), 14-15.

Ryan, Paul, Mike Moroney, Will Geoghegan, and James Cunningham (2007), "A Framework for a Strategic Repositioning Strategy: A Case Study of Bulmers Original Cider," Irish Journal of Management, 28(1), 81-102.

Shin, Su Yun and Jeong A Cho (2009), “A Study on the Repositioning of Korean Character/Career Women's Wear Brands: Focused on the Comparative Analysis with Import Masstige Brands," Research Journal of the Costume Culture, 17(1), 120-131 